\title{
A Study on Oxidative Stress Induced Cardiotoxicity by Cisplatin and Protective Evaluation by Tinospora cordifolia and vitamin C
}

\author{
Nisaath Begum $^{1 *}$, P. Shiva Kumar ${ }^{1}$, A. Gopala Reddy ${ }^{2}$, B. Ramya $^{3}$, \\ P. Kalyani ${ }^{4}$, B. Anil Kumar ${ }^{1}$ and M. Usha Rani ${ }^{1}$ \\ ${ }^{1}$ Department of Veterinary Pharmacology and Toxicology, \\ ${ }^{2}$ Department of Veterinary Pharmacology and toxicology and Registrar of PVNRTVU, \\ ${ }^{3}$ Department of Veterinary Clinical Complex, \\ ${ }^{4}$ Department of Veterinary Biotechnology, College of Veterinary Science, \\ Rajendranagar, Hyderabad - 500 030, Telangana, India \\ *Corresponding author
}

\section{A B S T R A C T}

Keywords

Cisplatin, Tinospora cordifolia, Vitamin C, Oxidative stress, Cardiotoxicity

Article Info

\section{Accepted:}

18 March 2021

Available Online:

10 April 2021
The ameliorative potential of Tinospora cordifolia (TC) and vitamin C (Vit. C) was studied against oxidative stress induced cardiotoxicity by cisplatin. 36 male Wistar rats were divided into 6 groups $(\mathrm{n}=6)$. Group 1 was maintained as Normal control. Cisplatin ( $7.5 \mathrm{mg} / \mathrm{kg} \mathrm{B.W})$ was administered intraperitoneally to the groups 2, 5 and 6 on day 1 . Groups 3 and 4 were administered for 14 days (p/o) with aqueous leaf extract of TC (400 mg/kg B.W) and vitamin C $(100 \mathrm{mg} / \mathrm{kg} \mathrm{B.W})$, respectively from day 1 . Group 5 and 6 received aqueous leaf extract of TC (400 mg/kg B.W) and vitamin C(100 mg/kg B.W), respectively for 14 days orally starting from the $1^{\text {st }}$ day of cisplatin injection. Body weights, antioxidant parameters and cytokine profile were assessed. The present study revealed a significant $(\mathrm{P}<0.05)$ increase in TBARS, protein carbonyls, TNF-alpha and IL-10, while significant $(\mathrm{P}<0.05)$ decrease in GSH in group 2 compared to group 1. The groups 5 and 6 showed significant improvement in all the parameters in comparison to group 2.In conclusion beneficial effects of $\mathrm{TC}$ and vitamin $\mathrm{C}$ could be attributed to their antioxidant and immunomodulatory actions.

\section{Introduction}

Cancer is leading cause of death worldwide (Oh et al., 2020), deaths due to cancer constitute $2-3 \%$ of the annual deaths recorded worldwide and kill about 3500 million people annually all over the world (Polu et al., 2017). Chemotherapy and Radiotherapy are common means of cancer treatment (Yanez et al., 2003). 
Cisplatin referred as Pencillin of cancer drugs and prescribed widely for first and effective treatment of cancer. Cisplatin used as gold standard by researchers against which new medicines are compared (Stephen, 2005). Cisplatin is one of the remarkable successes in 'the war on cancer'. It has activity against a broad spectrum of tumors, including testicular, bladder, cervical, ovarian, and lung cancers and solid tumors resistant to other treatment regimens (El-Awady et al., 2011).The anticancer mechanism of cisplatin includes the formation of highly reactive platinum complexes, which bind with nucleophilic DNA via intrastrand and interstrand crosslinking with guanine nucleotides (Hanigan and Devarajan, 2003), thus preventing DNA repair causing DNA damage and subsequent apoptosis within cancer cells (Aldossary, 2019). Life is harsh for cancer survivors (Katta et al., 2018). Despite definitive curative effect of cisplatin, major side effects of the cisplatin treatment include nephrotoxicity, cardiotoxicity, neurotoxicity, ototoxicity etc., thus limiting its clinical use. Several studies revealed cisplatin associated cardiotoxicity (Chowdhury et al., 2016). Cardiotoxicity is one of the most feared adverse effect of cisplatin chemotherapy (AlShimaa, 2017). Mechanism of toxicity due to cisplatin is related to its ability to generate ROS, such as superoxide anion and hydroxyl radical with the reduction of various antioxidants (Hussein et al., 2012).Oxidative stress plays a key role in cisplatin induced cardiotoxicity characterized by ROS production, lipid peroxidation and inhibition of antioxidant enzymes such as GSH, SOD and CAT. Excess of ROS target mitochondria resulting in mitochondrial dysfunction and subsequently induce caspase-dependent apoptosis (Zhao, 2019).

Plants have been one of the outstanding sources of medicines since the beginning of human civilization. There is flourishing demand for plant-based food supplements, pharmaceutical and health products (Joshi and Kaur, 2016). Tinospora cordifolia, commonly known as Amrita and Guduchi belongs to the family of Menispermaceae, is a succulent, glabrous woody climbing shrub native to India and thrives well in the tropical region. It is regarded as an essential herbal plant of Indian system of medicine and has been used in the treatment of fever, dysentery, diabetes, urinary problems, skin diseases, leprosy and many more diseases (Sharma et al., 2019).Different classes of compounds like alkaloids, diterpenoid lactones, sesquiterpenoids, glycosides, phenolics, steroids, aliphatic compounds and polysaccharides are identified as bioactive components of Tinospora cordifolia (Bonvicini et al., 2014).These compounds are found in various parts of the plant but highly concentrated in the leaves, stem and roots of the plant (Kumar et al., 2017). T.cordifoliahas anti-inflammatory, antispasmodic, anti-oxidant, anti-allergic, antimalarial, immunomodulatory. (Saha and Ghosh, 2012). The pharmacological activities could be attributed to the tannins, glucosides, polyphenols, catechins, epigallactocatechins etc., reported to have free radical scavenging activity(Singh et al., 2003). Most of the phytochemical components were found in aqueous extract due to high solubility of active compounds of Tinospora cordifolia leaf in this solvent (Madhavi et al., 2017).

Natural antioxidants protect the cells from oxidative injury (Ibrahim et al., 2019). Vitamin $\mathrm{C}$ is an important water-soluble vitamin known for antioxidant, immunomodulatory and anticarcinogenic actions (Tomofuji et al., 2009). Ghavamiand and Sardari, (2020) documented that vitamin C was efficient in reducing the systemic toxicity of cisplatin in mice model. Ray and Roy (2006) stated that vitamin $C$ increased the therapeutic index of the drug by reducing cisplatin-induced lipid-peroxidation mediated 
through free radical mechanisms. Antioxidants such as vitamin $\mathrm{C}$, vitamin $\mathrm{E}$, flavonoids and carotenoids have been reported to show protective effects in cisplatin induced toxicity (Koyuncu et al., 2017). In the light of these observations, an experimental study was framed to evaluate the protective effect of Tinospora cordifolia and vitamin $\mathrm{C}$ against oxidative stress induced cardiotoxicity by cisplatin.

\section{Materials and Methods}

\section{Chemicals}

All chemicals used were of analytical grade and obtained from Qualigens Pvt. Ltd., Mumbai and SRL Pvt. Ltd., Mumbai, India.

Plant material and Preparation of plant extract

The fresh leaves of Tinospora cordifolia plant were collected from Hyderabad, India. The plant species was authenticated by Scientist, Agricultural College, Hyderabad, India. Collected leaf material was washed under running tap water to eradicate dust and microbes and then shade dried at room temperature for 15 days. The leaf material was crushed well into fine powder in an electronic grinder and packed into airtight polythene bags for further use and stored at room temperature. Then, $5 \mathrm{gm}$ of dried powder is soaked in $100 \mathrm{ml}$ of water and shaken well. The solution was further kept at room temperature for 72 hours and then filtered with the help of Whatman No.1 filter paper (Madhavi et al., 2017). The filtrate was kept at low temperature $\left(4^{\circ} \mathrm{C}\right)$ for further use.

\section{Animals and Experimental Design}

Thirty six male Wistar rats aged about 3 months with an average bodyweight of $180 \pm$ $10 \mathrm{~g}$ were obtained from Vyas labs,
Hyderabad, which were divided into six equal groups $(n=6)$ with different treatments. The animals were housed in poly-propylene cages and maintained with $12 \mathrm{~h}$ dark/light cycle at college animal house under hygienic conditions having ambient temperature (20$22^{0} \mathrm{C}$ ) for acclimatization (1 week) prior to beginning of experiment. Animals were fed on standard balanced diet and water was supplied ad libitum throughout the experimental period. All the experimental procedures and protocols used in this study were reviewed and approved by the Institutional Animal Ethical Committee (No.4/22/C.V.Sc., Hyd. IAEC-Rats/ 29.02.2020) and were in accordance with the guidelines of the CPCSEA.

After experimental procedure, blood was collected. Feed was withdrawn $12 \mathrm{~h}$ prior to the blood collection and blood was collected from retro-orbital plexus into serum vacutainers and centrifuged at 3000 RPM for $15 \mathrm{~min}$ and serum was separated and stored at $-80^{\circ} \mathrm{C}$ till analysis. The serum samples were analyzed for cytokine profile (TNF-alpha and IL-10). On the $14^{\text {th }}$ day, after blood collection, rats were euthanized by carbon dioxide exposure and heart tissues were collected, homogenized and stored at $-80^{\circ} \mathrm{C}$ for further estimation of GSH, TBARS and protein carbonyls.

\section{Body weights}

Body weights were recorded on $0^{\text {th }}, 7^{\text {th }}$ and $14^{\text {th }}$ day.

\section{Antioxidant profile}

\section{Estimation of glutathione (GSH)}

GSH was estimated on the reaction of reduced glutathione (GSH) with 5-5, dithiobis-2nitrobenzoic acid (DTNB) to give a compound that absorbs light at $412 \mathrm{~nm}$ (Moron et al.,1979).100 $\mu \mathrm{l}$ of $25 \%$ trichloroacetic acid 
was added to $400 \mu \mathrm{l}$ of homogenate and then centrifuged, supernatant was collected and used. To $2.0 \mathrm{ml}$ of $0.6 \mathrm{mM}$ DTNB in $0.2 \mathrm{M}$ sodium phosphate $(\mathrm{pH} 8), 0.1 \mathrm{ml}$ of sample was added and $0.9 \mathrm{ml}$ of $0.2 \mathrm{M}$ phosphate buffer and the absorbance was read at $412 \mathrm{~nm}$ against a reagent blank. The standards $(0.05-5$ $\mathrm{mg} / \mathrm{ml}$ ) were also treated in the same manner.

\section{Estimation of Thiobarbituric acid reacting substances (TBARS)}

Malondialdehyde (MDA), the product of lipid peroxidation, estimated by reaction with thiobarbituric acid as per the procedure described by Balasubramanian et al.,(1988). 1 $\mathrm{g}$ of tissue sample with $10 \mathrm{ml}$ of $0.2 \mathrm{M}$ Tris $\mathrm{HCl}$ buffer $(\mathrm{pH} 7.2)$ was taken in a tissue homogenizer to get a $10 \%$ homogenate. $500 \mu \mathrm{l}$ of supernatant from the homogenate, $1 \mathrm{ml}$ of $10 \%$ trichloroacetic acid (TCA) and $1 \mathrm{ml}$ of $0.67 \%$ thiobarbituric acid were taken in a tightly stoppered tube. The tube was further heated to boiling temperature for $45 \mathrm{~min}$. After cooling the tube, the contents were centrifuged $(3500 \mathrm{rpm}, 10 \mathrm{~min})$. The supernatant absorbance was read against blank at $532 \mathrm{~nm}$. The concentration of test samples were obtained using molar extinction coefficient of MDA.

\section{Estimation of protein carbonyls}

Protein carbonyls were estimated based on the reaction of amino carbonyls with 2, 4dinitrophenyl hydrazine to form hydrazones, which can be detected spectrophotometrically at $372 \mathrm{~nm}$ (Levine et al.,1990). $1 \mathrm{ml}$ of homogenate supernatant containing $1 \mathrm{mg}$ protein was added to $4 \mathrm{ml}$ of $10 \mathrm{mM} \mathrm{DNPH}$ in $2.5 \mathrm{M} \mathrm{HCl}$. Samples were vortexed and incubated at room temperature for $1 \mathrm{~h}$ in dark.

Protein was then precipitated by adding $5 \mathrm{ml}$ of $20 \%$ trichloroacetic acid and centrifuged at $3000 \mathrm{rpm}$ for $10 \mathrm{~min}$, the supernatant was discarded to collect protein precipitate, which was washed thrice with $4 \mathrm{ml}$ of ethanol: ethyl acetate (1:1) solution. The final protein precipitate was re-dissolved in $2 \mathrm{ml}$ of $6 \mathrm{M}$ guanidine $\mathrm{HCl}$ in $20 \mathrm{mM}$ of potassium phosphate and kept at $370 \mathrm{C}$ for $10 \mathrm{~min}$ and was further centrifuged to remove the insoluble substances and the absorbance was read at $372 \mathrm{~nm}$ against $2.5 \mathrm{M} \mathrm{HCl}$ blank.

A known concentration of bovine serum albumin dissolved in $6 \mathrm{M}$ guanidine $\mathrm{HCl}$ in 20 $\mathrm{mM}$ of potassium phosphate was used as standard.

\section{Cytokine profile}

The assay employs a quantitative sandwich enzyme immunoassay technique to measure TNF - alpha and IL-10. The ELISA kit was procured from Krishgen Bio systems, Mumbai.

\section{Statistical Analysis}

Data were subjected to statistical analysis by applying one-way analysis of variance (ANOVA) using the statistical package for social sciences (SPSS; version 21). followed by Duncan's test as post hoc analysis. The value of $\mathrm{P}<0.05$ was considered to be statistically significant.

\section{Results and Discussion}

In the present study, antioxidant profile, cytokine profile and were analyzed on $14^{\text {th }}$ day. The results obtained in the present experiment are presented as below. The mean body weight (g) in group 2 was significantly $(\mathrm{P}<0.05)$ decreased on $7^{\text {th }}$ and $14^{\text {th }}$ day, when compared to group 1 , while treatment groups 5 and 6 showed significant $\quad(\mathrm{P}<0.05)$ improvement in their body weights during the experimental period.(Table 1; Fig. 1). 
The concentration of GSH ( $\mu \mathrm{mol} / \mathrm{mg}$ protein) in heart revealed a significant $(\mathrm{P}<0.05)$ decrease in toxic control group 2 when compared to group 1, whereas treatment groups 5 and 6 revealed a significant $(\mathrm{P}<0.05)$ improvement as compared to toxic control group 2 (Table 1; Fig. 2).

The concentration of TBARS ( $\mathrm{n}$ moles of MDA released/mg protein) (Table 1; Fig. 3) and protein carbonyls (n moles of carbonyl/mg protein) (Table 1; Fig. 4), in heart revealed a significant $(\mathrm{P}<0.05)$ increase in toxic control group 2 when compared to group 1, whereas treatment groups 5 and 6 showed a significant $(\mathrm{P}<0.05)$ decrease as compared to toxic control group 2.

The concentration of serum TNF- $\alpha$ $(\mathrm{pg} / \mathrm{ml})($ Table 1; Fig. 5) and IL-10 (pg/ml) (Table 1; Fig. 6)revealed a significant $(\mathrm{P}<0.05)$ increase in toxic control group 2 when compared to group 1 , whereas treatment groups 5 and 6 showed a significant $(\mathrm{P}<0.05)$ decrease as compared to toxic control group 2.

Values are Mean + SE (n =6); One way ANOVA with Duncan's post hoc test (SPSS).

Means with different alphabets as superscripts differ significantly $(\mathrm{P}<0.05)$ among the groups (Vertically).

Decrease in food intake and weight loss are the most serious and common health problems in patients with cisplatin chemotherapy (Lin $e t$ al., 2018).Weight loss observed in the cisplatin treated group may be because of reduced appetite and enhanced catabolic rate seen as obvious side effects of chemotherapy. It could also be due to $\mathrm{CP}$ induced dysfunction of the gastrointestinal system (Hassan et al., 2010).Cisplatin shows dose- dependent gastric stasis and stomach distension associated with food retention and responsible for reduced feed intake (Cabezos et al., 2008). Factors such as nausea and vomiting, diarrhoea, constipation, altered taste and depression are responsible for cisplatin chemotherapy associated weight loss(Yoshizawa et al., 2019). In the present study, the body weights of rats in toxic control group 2 were significantly reduced when compared to nontoxic control groups (1,3 and 4) at respective time intervals i.e., on $7^{\text {th }}$ and $14^{\text {th }}$ day. The decrease in body weights in cisplatin group is attributed to oxidative stress and ROS generation, which leads to altered metabolism (Kumar et al., 2017). The results are in concurrence with the findings of Zhao et al., (2018) and Afsar et al., (2019), who reported that cisplatin treatment resulted in significant reduction in body weights in mice and rats, respectively. Weight gain observed in the treated animals (groups 5 and 6) may be due to restoration of antioxidant defenses as evident from the findings of this study. Significant increase in the average weekly body weight with Tinospora cordifolia against various toxicitieswas also reported by Ambasta et al., (2017) in mice against arsenic induced toxicity and Nageswari et al., (2018) in rats against zidovudine induced immunotoxicity.

In our present study, there is significant decrease in GSH and increase in TBARS and protein carbonyls in heart tissue of rats of the toxic control group 2 when compared to the non-toxic groups 1, 3 and 4.MDA plays a vital role in the toxicity of several xenobiotics (Koyuncu et al., 2017). MDA, the end product of lipid peroxidation, is the most important indicator of the oxidative damage. In oxidative damage, there is an increase in the amount of MDA and decrease in the amount of endogenous antioxidant molecule GSH (Nooriand Mahboob, 2010). Increase in the MDA level attributes to cisplatin-induced generation of oxygen free radicals, which evoke extensive tissue damage, reacting with membrane lipids, proteins and nucleic acids 
(Satoh et al., 2003;Conklin and Nicolson, 2008; Topal et al., 2018), resulting in oxidative stress which plays an important role in cisplatin cardiotoxicity (Afsar et al., 2019).GSH, an omnipresent intracellular peptide, has various functions such as maintaining cellular antioxidant and oxidant balance, detoxification, maintenance of thiol and modulation of cell proliferation (Koyuncu et al., 2017).The decline in GSH level in cisplatin-treated rats resulted in an enhanced lipid peroxidation (Karthikeyan et al., 2007). ROS production by cisplatin inhibits GSH by interfering with its disulfide bond, Cardiac GSH depletion during oxidative stress results in accumulation of GSSG and results in impaired cell function. Superoxide anion radicalis responsible for endothelial dysfunctioning in cardiovascular diseases (Chowdhury et al., 2016). Depletion of GSH and related antioxidants by cisplatin shifts the cellular redox status, results in the accumulation of endogenous reactive oxygen species within the cells (Arany and Safirstein, 2003).Wang et al., (2009) confirmed that myocardial damage is responsible for the increased levels of MDA and decreased activities of GSH, SOD, CAT and GSH-Px. Thus, the findings are in concurrence with the studies depicting that oxidative damage plays an important role in cisplatin induced cardiotoxicity.

Cardiac tissue has very low level of antioxidant enzymes such as superoxide dismutase and catalase, thus heart is the most susceptible organ to oxidative stress(Al-Majed et al., 2006). The observed decrease in heart GSH levels, increase in MDA levels and decreased activities of SOD are suggestive of the oxidative stress caused by cisplatin treatment (El-Awady et al., 2011). The results are in concurrence with the findings of Kiran et al., (2015), who reported that up-regulated levels of MDA and down-regulated activity of antioxidant defenses like GSH result in cisplatin-induced cardiotoxicity.

Proteins are damaged by ROS directly and are the targets of secondary modifications by aldehyde products of lipid peroxidation or ascorbate autooxidation, further resulting in carbonyl modification of protein (PCO). The assessment of PCO is a widely used marker for oxidative protein modification and it is sensitive and early marker of oxidative stress to tissues as compared to lipid peroxidation (Ilaiyarajaand Khanum, 2011).

Oxidative modification of proteins leads to loss of protein function and shows detrimental effects on cell and tissues (Dalle-Donne et al., 2003). The results are in accordance with the findings of Rjiba et al., (2012), who reported that cisplatin induces significant increase in protein carbonyl generation and decreases the levels of GSH in heart of rats. Hassan et al., (2010) stated that carbonyls and MDA contents are considered respectively as final products for estimation of protein oxidation and lipid peroxidation, respectively and reported that cisplatin treated rats showed tremendous increment in MDA content and carbonyl content. Our findings revealed that $T$. cordifolia and vitamin $\mathrm{C}$ administration increased GSH levels, suppressed the increase in MDA concentration (an index of lipid peroxidation) and suppressed the increase in protein carbonyls (an index of protein degradation). These findings suggest that protective action of Tinospora cordifolia is in harmony with the previous reports (Stanley and Menon 2001; Goel et al., 2002). T.cordifolia extract inhibits the lipid peroxidation and superoxide and hydroxide radicals in vitro due to its antioxidant and free radical scavenging properties (Mathewand Kuttan, 1997). 
Table.1 Experimental design

\begin{tabular}{|c|c|}
\hline Group 1 & Normal saline orally for 14 days \\
\hline Group 2 & Cisplatin $(7.5 \mathrm{mg} / \mathrm{kg}$ body weight, ip) injection on day 1 . \\
\hline Group 3 & $\begin{array}{c}\text { Aqueous leaf extract of Tinospora cordifolia @ } 400 \mathrm{mg} / \mathrm{kg} \text { body weight was } \\
\text { orally administered for } 14 \text { days starting from the day } 1 .\end{array}$ \\
\hline Group 4 & $\begin{array}{c}\text { Vitamin C @ } 100 \mathrm{mg} / \mathrm{kg} \text { body weight was orally administered for } 14 \text { days } \\
\text { starting from the day } 1 .\end{array}$ \\
\hline Group 5 & $\begin{array}{c}\text { Cisplatin }(7.5 \mathrm{mg} / \mathrm{kg} \text {, ip) injection on day } 1+\text { Aqueous leaf extract of } \\
\text { Tinospora cordifolia @ } 400 \mathrm{mg} / \mathrm{kg} \text { body weight was orally administered for } \\
14 \text { days starting from the day } 1\end{array}$ \\
\hline Group 6 & $\begin{array}{l}\text { Cisplatin }(7.5 \mathrm{mg} / \mathrm{kg} \text {, ip) injection on day } 1+\text { Vitamin C @ } 100 \mathrm{mg} / \mathrm{kg} \text { body } \\
\text { weight was orally administered for } 14 \text { days starting from the day } 1 .\end{array}$ \\
\hline
\end{tabular}

Table.2 Average body weights (g), GSH ( $\mu$ mol /mg protein),TBARS (nm MDA released/mg protein), Protein carbonyls (nmoles of carbonyl $/ \mathrm{mg}$ protein), TNF-alpha (pg/ml) and IL-10

$(\mathrm{pg} / \mathrm{ml})$ in different groups of rats.

\begin{tabular}{|c|c|c|c|c|c|c|}
\hline Parameter & $\begin{array}{l}\text { Normal } \\
\text { Control }\end{array}$ & Cisplatin & TC & Vit. C & $\begin{array}{c}\text { Cisplatin } \\
+ \\
\text { TC }\end{array}$ & $\begin{array}{c}\text { Cisplatin } \\
+ \\
\text { Vit.C }\end{array}$ \\
\hline $\begin{array}{c}\text { Day } 7 \\
\text { body weight }\end{array}$ & $\begin{array}{r}220.66 \pm \\
1.02^{\mathrm{a}}\end{array}$ & $\begin{array}{c}135.50 \pm \\
0.42^{\mathrm{c}}\end{array}$ & $\begin{array}{l}220.50 \\
\pm 0.76^{\mathrm{a}}\end{array}$ & $\begin{array}{l}221.50 \\
\pm 1.72^{\mathrm{a}}\end{array}$ & $\begin{array}{c}160.66 \pm \\
1.58^{\mathrm{b}}\end{array}$ & $\begin{array}{c}161.16 \pm \\
1.01^{\mathrm{b}}\end{array}$ \\
\hline $\begin{array}{c}\text { Day } 14 \\
\text { body weight }\end{array}$ & $\begin{array}{c}246.50 \pm \\
2.89^{\mathrm{a}}\end{array}$ & $\begin{array}{c}133.16 \pm \\
0.79^{\mathrm{c}}\end{array}$ & $\begin{array}{l}247.50 \\
\pm 2.37^{\mathrm{a}}\end{array}$ & $\begin{array}{l}248.66 \\
\pm 3.81^{\mathrm{a}}\end{array}$ & $\begin{array}{c}194.00 \pm \\
0.93^{\mathrm{b}}\end{array}$ & $\begin{array}{c}195.50 \pm \\
1.33^{\mathrm{b}}\end{array}$ \\
\hline GSH & $\begin{array}{l}9.63 \pm \\
0.22^{\mathrm{a}}\end{array}$ & $\begin{array}{l}4.98 \pm \\
0.27^{c}\end{array}$ & $\begin{array}{l}9.68 \pm \\
0.23^{\mathrm{a}}\end{array}$ & $\begin{array}{l}9.75 \pm \\
0.18^{a}\end{array}$ & $\begin{array}{l}7.03 \pm \\
0.22 \mathrm{~b}\end{array}$ & $\begin{array}{l}7.49 \pm \\
0.24^{b}\end{array}$ \\
\hline TBARS & $\begin{array}{l}55.50 \pm \\
1.74^{\mathrm{c}}\end{array}$ & $\begin{array}{l}77.83 \pm \\
1.70^{\mathrm{a}}\end{array}$ & $\begin{array}{c}54.66 \pm \\
1.45^{\mathrm{c}}\end{array}$ & $\begin{array}{c}53.16 \pm \\
1.44^{\mathrm{c}}\end{array}$ & $\begin{array}{c}61.66 \pm \\
1.22^{\mathrm{b}}\end{array}$ & $\begin{array}{c}60.33 \pm \\
1.38^{\mathrm{b}}\end{array}$ \\
\hline $\begin{array}{c}\text { Protein } \\
\text { carbonyls }\end{array}$ & $\begin{array}{l}1.75 \pm \\
0.08^{c}\end{array}$ & $\begin{array}{l}7.36 \pm \\
0.42^{\mathrm{a}}\end{array}$ & $\begin{array}{l}1.58 \pm \\
0.05^{\mathrm{c}}\end{array}$ & $\begin{array}{l}1.49 \pm \\
0.03^{\mathrm{c}}\end{array}$ & $\begin{array}{l}3.36 \pm \\
0.23^{b}\end{array}$ & $\begin{array}{l}3.03 \pm \\
0.18^{b}\end{array}$ \\
\hline TNF-alpha & $\begin{array}{r}106.83 \pm \\
4.24^{\mathrm{c}}\end{array}$ & $\begin{array}{c}381.83 \pm \\
7.43^{\mathrm{a}} \pm\end{array}$ & $\begin{array}{l}105.50 \\
\pm 2.21^{c}\end{array}$ & $\begin{array}{l}105.83 \\
\pm 4.54^{c}\end{array}$ & $\begin{array}{c}230.00 \pm \\
4.95^{\mathrm{b}}\end{array}$ & $\begin{array}{c}227.33 \pm \\
2.06^{\mathrm{b}}\end{array}$ \\
\hline IL-10 & $\begin{array}{c}54.50 \pm \\
1.50^{\mathrm{c}}\end{array}$ & $\begin{array}{c}374.50 \pm \\
1.08^{\mathrm{a}}\end{array}$ & $\begin{array}{c}53.83 \pm \\
1.30^{\mathrm{c}}\end{array}$ & $\begin{array}{c}52.16 \pm \\
0.83^{\mathrm{c}}\end{array}$ & $\begin{array}{c}294.16 \pm \\
3.68^{\mathrm{b}}\end{array}$ & $\begin{array}{c}291.50 \pm \\
4.77^{\mathrm{b}}\end{array}$ \\
\hline
\end{tabular}


Fig.1 Average body weights ( $\mathrm{g}$ ) of rats of different groups of rats

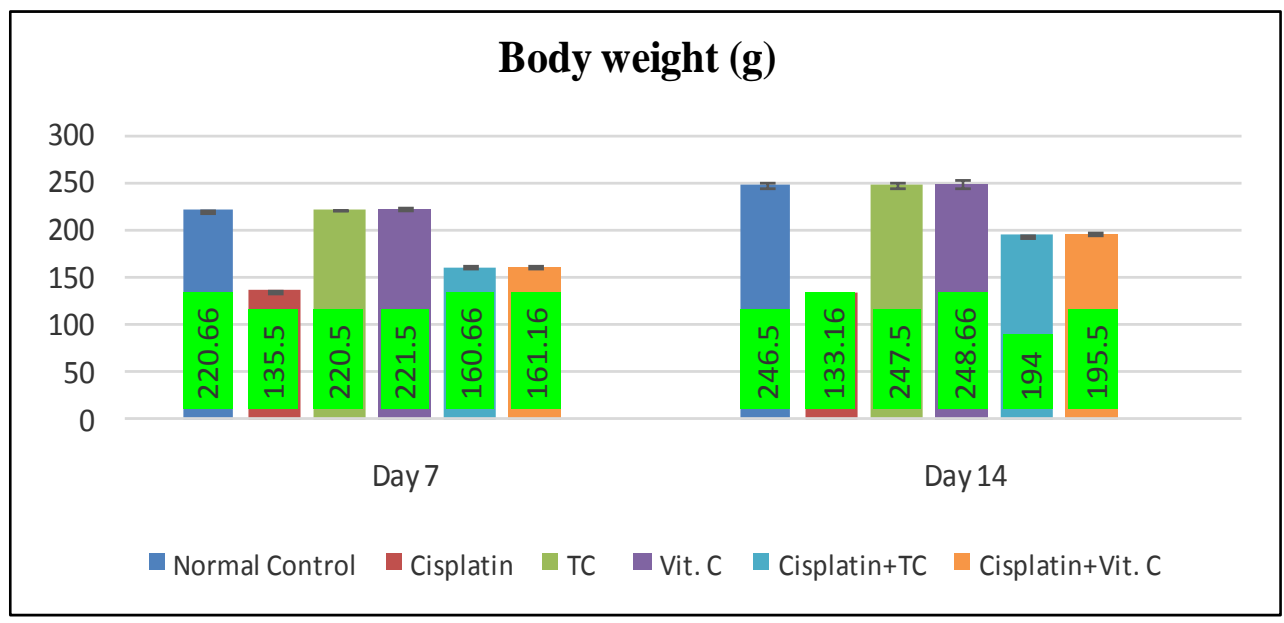

Fig.2 GSH concentration ( $\mu \mathrm{mol} / \mathrm{mg}$ protein) in heart of different groups of rats

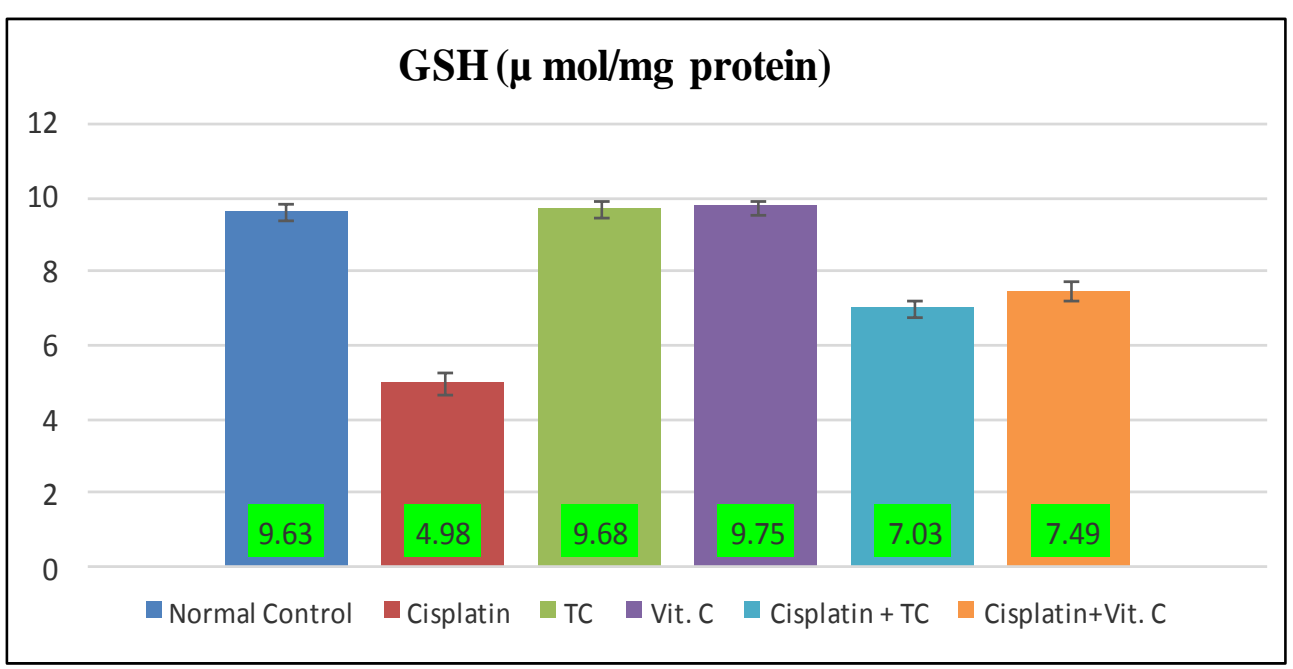


Fig.3 TBARS concentration (n moles of MDA released/mg protein) in heart of different groups of rats

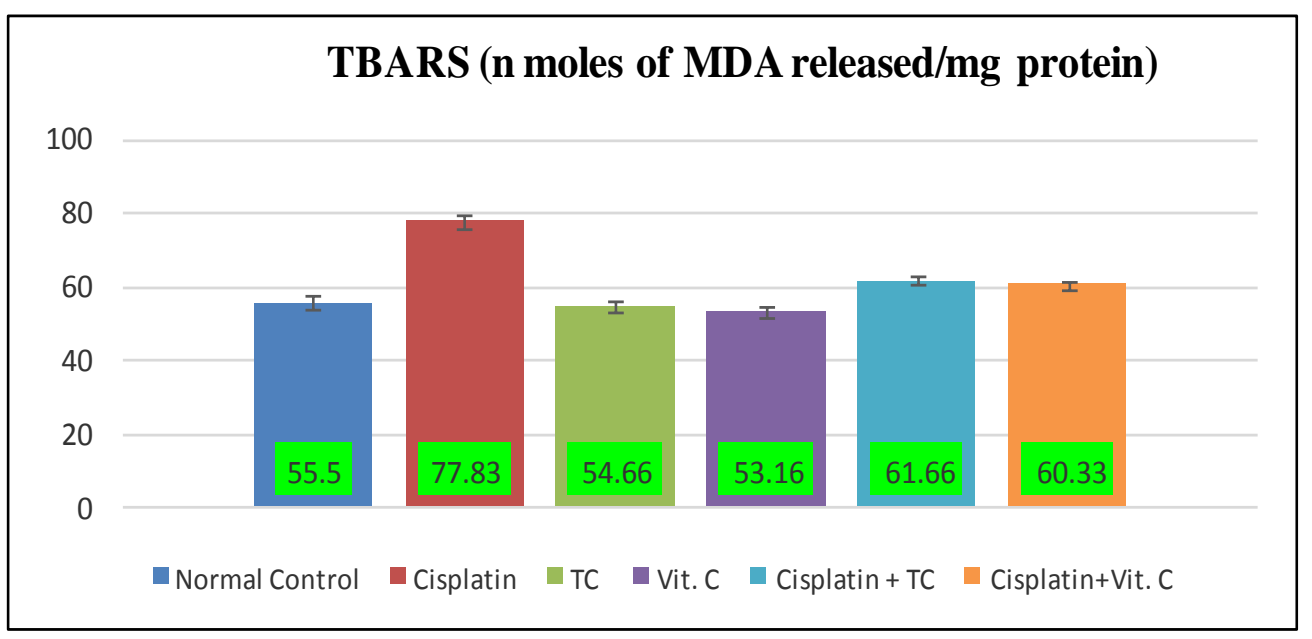

Fig.4 Protein carbonyl concentration (n moles of carbonyl/mg protein) in heart of different groups of rats

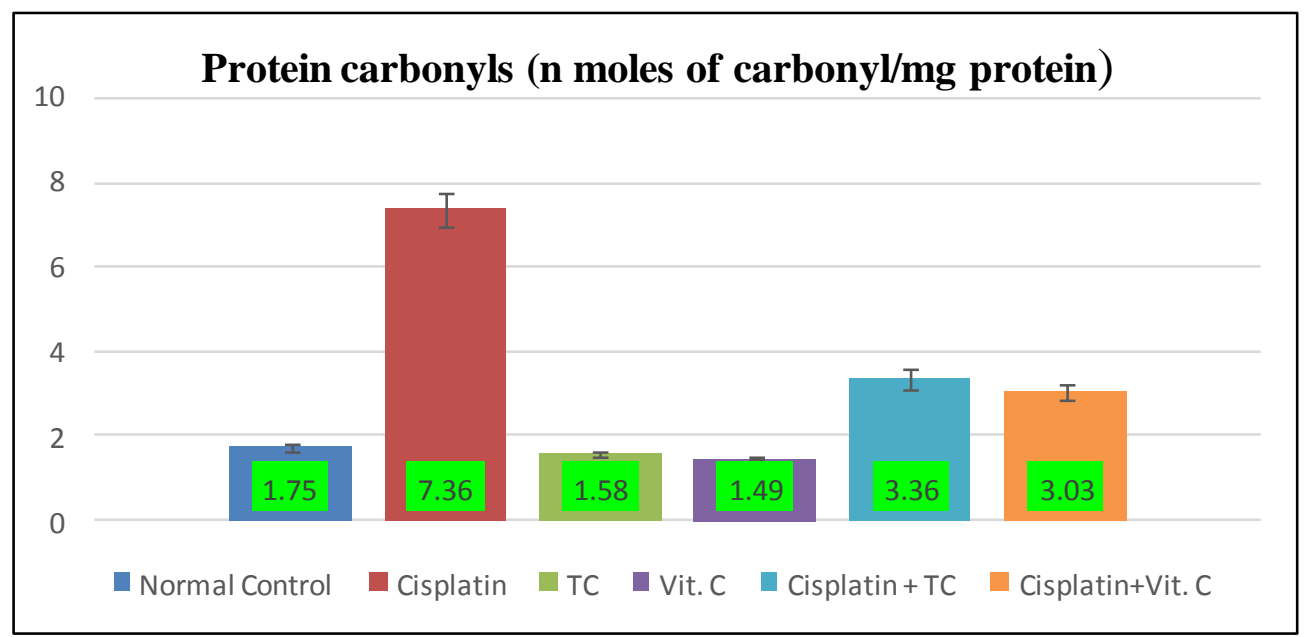


Fig.5 Serum TNF- $\alpha$ levels (pg/ml)in different groups of rats

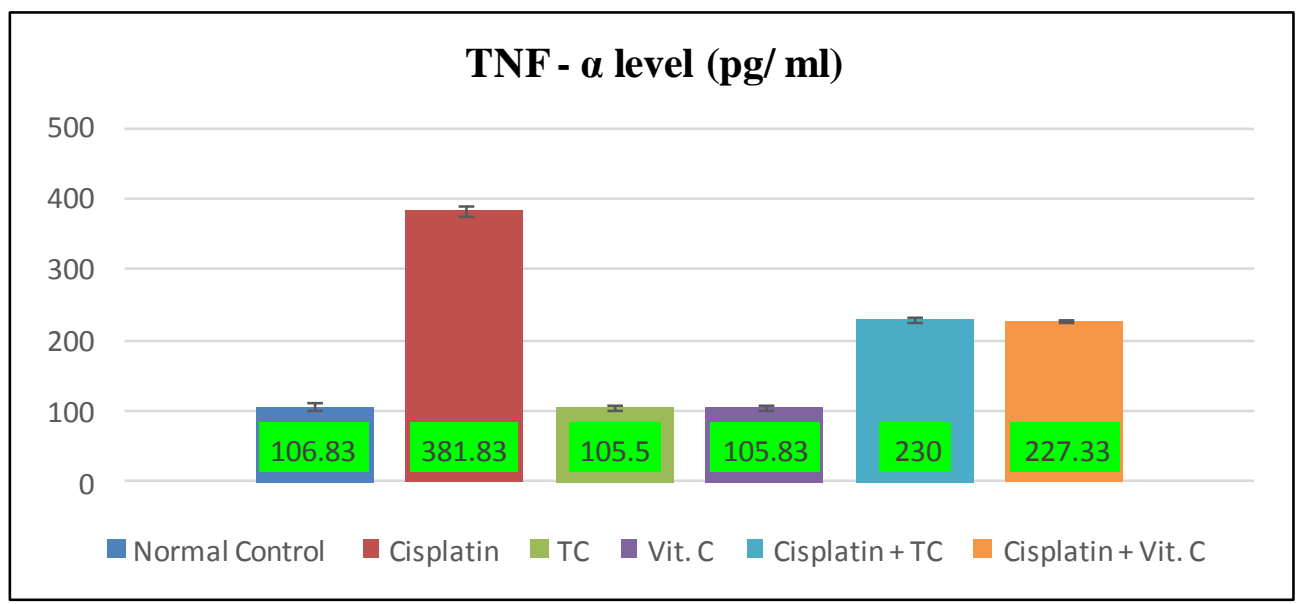

Fig.6 Serum IL-10 levels (pg/ml) in different groups of rats

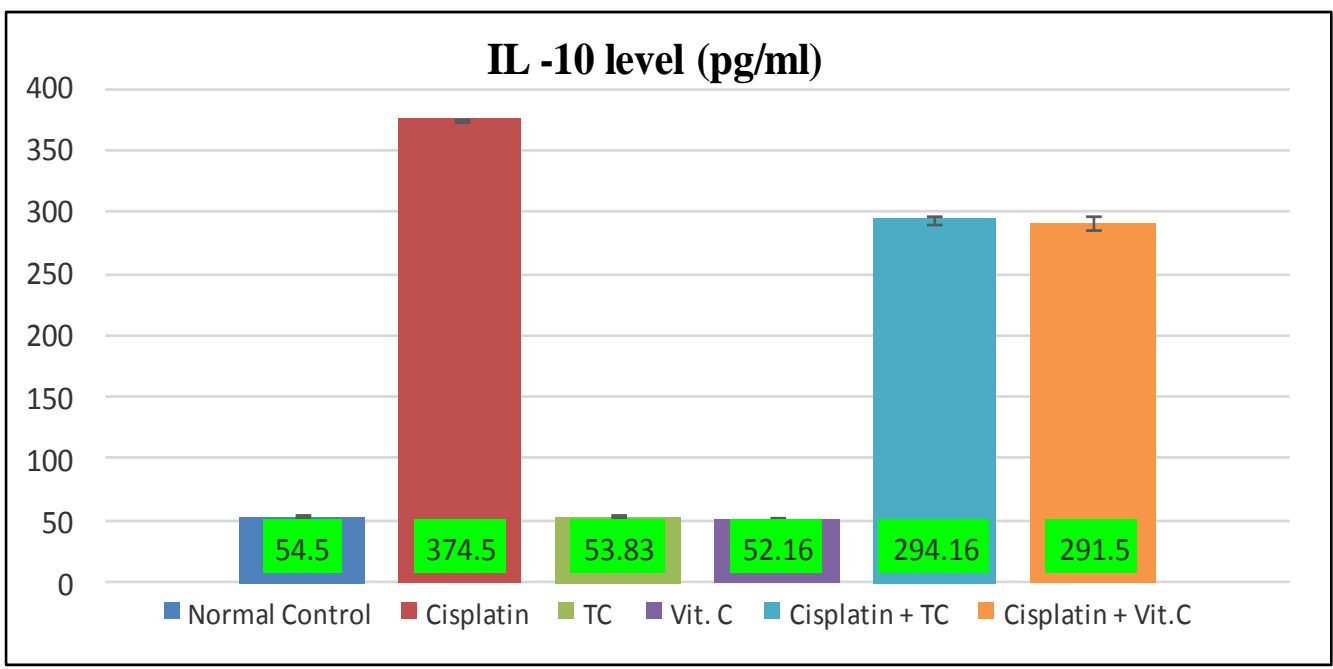

The aqueous extract of $T$. cordifolia leaves revealed the presence of phytosterols, flavonoids, phenols and diterpenes (Madhavi et al., 2017). Phenolic compounds exhibit antioxidant potential, by scavenging the free radicals. Due to the presence of hydroxyl group and redox properties, they act as reducing agents, hydrogen donors, singlet oxygen quenchers and metal chelators (Polu et al., 2017). Flavonoids act as scavengers of many oxidizing species (hydroxyl radical or peroxy-radicals and superoxide anions) and as quenchers of singlet oxygen (Kaur et al.,
2016). In the present study, there is significant increase in serum TNF- $\alpha$ and IL-10 in toxic control group 2 compared to the nontoxic groups 1, 3 and 4 . IL-10 is a pleiotropic cytokine produced by macrophages, Blymphocytes and T-helper 2 (Th2) cells, which can stimulate and suppress the immune response (Othman et al., 2013). Concurrent with the induction of a stress-activated inflammatory response, many agents with anti-inflammatory properties (IL-10) are produced that may prevent tissue injury or help in tissue repair/remodeling subsequent to 
injury in different organs and tissues (Deng et al., 2001).Our results are in accordance with the findings of Chowdhury et al., (2016), who reported increased levels of TNF- $\alpha$ (responsible for tissue damage) in the cardiac tissue of animals following cisplatin administration. TNF- $\alpha$ intensifies the cytotoxic effects of cisplatin. Tumor cells exhibit an elevation in constitutive production of several pro-inflammatory cytokines such as TNF- $\alpha$, IL- 6 and IL-1 $\beta$. They are major mediators of acute inflammation and play decisive roles at different stages of development of tumor, including initiation, promotion, malignant conversion, invasion, and metastasis. Apoptosis and myocyte necrosis can be linked to elevated proinflammatory cytokine levels, such as IL$1 \beta$, TNF- $\alpha$, and interferon- $\gamma$. Enhanced levels of TNF- $\alpha$ suggests stimulation of the inflammatory response in vivo, which leads to aggravated cisplatin-induced cardiotoxicity (Bahadir et al., 2018). Cytokines, chemokines and cell adhesion molecules together regulate the neutrophil infiltration at the site of cardiac tissue damage. Inflammation related genes for pro-inflammatory cytokines, chemokines and cell adhesion molecules are mostly regulated by the transcription factor NF- $\mathrm{KB}$. Cisplatin mediated ROS generation activates the transcription factor NF- $\mathrm{BB}$, which plays a critical role in cardiac inflammation and injury (Chowdhury et al., 2016).

In the present study, T.cordifolia and vitamin $\mathrm{C}$ at the doses administered significantly normalized the elevated level of inflammatory cytokines and thus protected the heart from inflammatory insult. Spelman et al., (2006) reviewed the immunomodulatory activity of T.cordifoliain vitro and in vivo, and found that it plays a prominent role in the modification of modulation of Il -1, Il-6, TNF and INF.Dry leaf extracts of T.cordifoliahave been reported to exhibit anti-inflammatory activity by inhibiting LPS-induced pro-inflammatory cytokine TNF- $\alpha$, at both protein and transcript levels (Reddi and Tetali, 2019).

In conclusion, the study revealed that cisplatin induces cardiotoxicity by oxidative stress. Administration of Tinospora cordifolia and vitamin $\mathrm{C}$ could effectively antagonize the cardiotoxicity by cisplatin owing to their antioxidant and cardioprotective actions.

\section{Acknowledgment}

The authors thank the College of veterinary science, PVNR TVU, Rajendranagar, Hyderabad for providing technical assistance for research work.

\section{References}

Afsar T, Razak S, Almajwal A, Shabbir M and Khan M R. 2019. Evaluating the protective potency of Acacia hydaspica R. Parker on histological and biochemical changes induced by Cisplatin in the cardiac tissue of rats. Bio Med Central Complementary and Alternative Medicine. 19(1) :1-12.

Aldossary S A. 2019. Review on pharmacology of cisplatin: Clinical use, toxicity and mechanism of resistance of cisplatin. Biomedical and Pharmacology Journal. 12(1): 7-15.

Al-Majed A A, Sayed-Ahmed M M, Al-Yahya A A, Aleisa A M, Al-Rejaie S S, and Al-Shabanah O A. 2006. Propionyl-Lcarnitine prevents the progression of cisplatin-induced cardiomyopathy in a carnitine-depleted rat model. Pharmacological Research. 53(3): 278286.

Al-Shimaa M A. 2017. Evaluation of the Protective Effects of Ginger Extract on Cisplatin Induced Cardiotoxicity in Male Albino Rats. Journal of Chemical and Pharmaceutical Research9. (2): 99-110. 
Ambasta S K, Kumari S and Sinha U K. 2017. Anticlastogenicity of Tinospora cordifolia stem extract against arsenic genotoxicity in Mus musculus bone marrow erythrocytes using micronucleus assay. International Journal of Pharmacy and Pharmaceutical Sciences. 9(10): 260-4.

Arany I and Safirstein R L. 2003, September. Cisplatin nephrotoxicity. In Seminars In Nephrology. 23 (5): 460-464. WB Saunders.

Bahadır A, Ceyhan A, Gergin O O, Yalcın B, Ulger M, Ozyazgan T M and Yay A. 2018. Protective effects of curcumin and beta-carotene on cisplatin-induced cardiotoxicity: An experimental rat model. Anatolian Journal of Cardiology. 19(3): 213.

Balasubramanian $\mathrm{K}$ A, Manohar $\mathrm{M}$ and Mathan V I. 1988. An unidentified inhibitor of lipid peroxidation in intestinal mucosa. Biochimica et Biophysica Acta. 962(1): 51-58

Bonvicini F, Mandrone M, Antognoni F, Poli F, and Angela Gentilomi G. 2014. Ethanolic extracts of Tinospora cordifolia and Alstonia scholaris show antimicrobial activity towards clinical isolates of methicillin-resistant and carbapenemase-producing bacteria. Natural Product Research. 28 (18): 1438-1445.

Cabezos P A, Vera, Castillo M, FernandezPujol R, Martin M I and Abalo R. 2008. Radiological study of gastrointestinal motor activity after acute cisplatin in the rat: Temporal relationship with pica. Autonomic Neuroscience. 141(1-2): 54-65.

Chowdhury S, Sinha K, Banerjee S and Sil P C. 2016. Taurine protects cisplatin induced cardiotoxicity by modulating inflammatory and endoplasmic reticulum stress responses. Biofactors. 42(6): 647-664.
Conklin K A and Nicolson G L. 2008. Molecular replacement in cancer therapy: reversing cancer metabolic and mitochondrial dysfunction, fatigue and the adverse effects of therapy. Current Cancer Therapy Reviews. 4(1): 66-76.

Dalle-Donne I, Giustarini D, Colombo R, Rossi R and Milzani A.2003. Protein carbonylation in human diseases. Trends In Molecular Medicine. 9(4): 169-176.

Dasari S and Tchounwou P B. 2014. Cisplatin in cancer therapy: molecular mechanisms of action. European Journal of Pharmacology. 740: 364378.

Deng J, Kohda Y, Chiao H, Wang Y, Hu X, Hewitt S M and Star R A. 2001. Interleukin-10 inhibits ischemic and cisplatin-induced acute renal injury. Kidney International. 60(6): 21182128 .

El-Awady E S E, Moustafa Y M, Abo-Elmatty D M and Radwan A. 2011. Cisplatininduced cardiotoxicity: Mechanisms and cardioprotective strategies. European Journal of Pharmacology. 650(1): 335-341.

Ghavami G and Sardari S. 2020. Synergistic effect of vitamin $\mathrm{C}$ with cisplatin for inhibiting proliferation of gastric cancer cells. Iranian Biomedical Journal. 24(2): 119.

Goel H C, Prem Kumar I, Rana S V. 2002. Free radical scavenging and metal chelation by Tinospora cordifolia, a possible role in radioprotection. Indian Journal of Experimental Biology. 40(6): 727-734.

Hanigan M H and Devarajan P. 2003. Cisplatin nephrotoxicity: molecular mechanisms. Cancer therapy 1: 47.

Hassan I, Chibber S and Naseem I. 2010. Ameliorative effect of riboflavin on the cisplatin induced nephrotoxicity 
and hepatotoxicity under photoillumination. Food and Chemical Toxicology. 48(8-9): 2052-2058.

Hussein A, Ahmed A A, Shouman S A and Sharawy S. 2012. Ameliorating effect of DL- $\alpha$-lipoic acid against cisplatininduced nephrotoxicity and cardiotoxicity in experimental animals. Drug Discoveries \& Therapeutics. 6(3): 147-156.

Ibrahim M A, Bakhaat G A, Tammam H G, Mohamed R M and El-Naggar S A. 2019. Cardioprotective effect of green tea extract and vitamin E on Cisplatininduced cardiotoxicity in mice: Toxicological, histological and immunohistochemical studies. Biomedicine and Pharmacotherapy. 113: 108731.

Ilaiyaraja N and Khanum F. (2011). Antioxidant potential of Tinospora cordifolia extracts and their protective effect on oxidation of biomolecules. Pharmacognosy Journal. 3(20): 56-62.

Joshi G and Kaur R. 2016. Tinospora cordifolia: a phytopharmacological review. International Journal of Pharmaceutical Sciences and Research. 7(3): 890.

Karthikeyan K, Bai B S and Devaraj S N. 2007. Cardioprotective effect of grape seed proanthocyanidins on isoproterenol-induced myocardial injury in rats. International Journal of Cardiology. 115(3): 326-333.

Katta S, Chauhan S, Singh A, Shetty P N, Kareem H and Devasia T. 2018. Cisplatin-Etoposide Induced Myocardial Infarction in a Patient with Small Cell Carcinoma. Journal of Applied Pharmaceutical Science. 8(05): 139-142.

Kaur G, Prabhakar P K, Lal U R and Suttee A. 2016. Phytochemical and biological analysis of Tinospora cordifolia. International Journal of Toxicological and Pharmacological Research. 8(4): 297-305.

Kiran B U, Sushma M, Prasad K V S R G, Rao V U M, Bai D J L and Nisheetha V. 2015. Antioxidant and radical scavenging properties of $\beta$-carotene on cisplatin induced cardiotoxicity. Cardiology and Angiology: An International Journal. 98-106.

Koyuncu I, Kocyigit A, Gonel A, Arslan E and Durgun M. 2017. The protective effect of naringenin-oxime on cisplatin-induced toxicity in rats. Biochemistry Research International, 1-9.

Kumar D V, Geethanjali B, Avinash K O, Kumar J R and Basalingappa K M. 2017. Tinospora cordifolia: The antimicrobial property of the leaves of amruthaballi. Journal of Bacteriology and Mycology. Open Access. 5: 363371.

Levine R L, Garland D, Oliver C N, Amici A, Climent I, Lenz A G, Ahn B W, Shaltiel S and Stadtman E R. 1990. Determination of carbonyl content in oxidatively modified proteins. Methods in Enzymology. 186: 464478.

Lin M T, Ko J L, Liu T C, Chao P T and Ou C C. 2018. Protective Effect of DMethionine on Body Weight Loss, Anorexia, and Nephrotoxicity in Cisplatin-Induced Chronic Toxicity in Rats. Integrative Cancer Therapie. 17(3):813-824.

Madhavi A, Vijaylaxami A and Narasimha V. 2017. Preliminary phytochemical analysis of Guduchi C Tinospora cordifolia (Willd) Miers leaf in different solvent extracts. International Ayurvedic Medical Journal. 5(5): 1500-1505.

Mathew S and Kuttan G. 1997. Antioxidant activity of Tinospora cordifolia and its usefulness in the amelioration of 
cyclophosphamide induced toxicity. Journal of Experimental \&Clinical Cancer Research. 16(4): 407-411.

Moron M S, Depierre J W and Mannervik B. 1979. Levels of glutathione, glutathione reductase and glutathione $\mathrm{S}$ transferase in rat lung and liver. Biochimica et Biophysica Acta. 582: 67-68.

Nageswari G, Reddy A H and Venkatappa B. 2018. Evaluation of immunomodulatory effect of Tinospora cordifolia leaf and stem on zidovudine induced immunotoxicity. International Journal of Scientific Research in Biological Sciences. 5(3): 1-5.

Noori S and Mahboob T. 2010. Antioxidant effect of carnosine pretreatment on cisplatin-induced renal oxidative stress in rats. Indian Journal of Clinical Biochemistry. 25(1): 86-91.

Oh C M, Lee D, Kong H J, Lee S, Won Y J, Jung K W and Cho H. 2020. Causes of death among cancer patients in the era of cancer survivorship in Korea: attention to the suicide and cardiovascular mortality. Cancer Medicine. 9(5): 1741-1752.

Othman M S, Aref A M, Mohamed A A and Ibrahim W A. 2013. Serum Levels of Interleukin-6 and Interleukin-10 as biomarkers for hepatocellular carcinoma in Egyptian Patients. International Scholarly Research Notices Hepatology.412317.

Polu P R, Nayanbhirama U, Khan S, and Maheswari R. 2017. Assessment of free radical scavenging and antiproliferative activities of Tinospora cordifolia Miers (Willd). BioMed Central Complementary and Alternative Medicine. 17(1): 457.

Ray S and Roy K. 2006. Cisplatin-induced lipid peroxidation and its inhibition with ascorbic acid. IndianJournal of
Pharmaceutical Sciences. 68(2): 199204.

Reddi K K and Tetali S D. 2019. Dry leaf extracts of Tinospora cordifolia (Willd.) Miers attenuate oxidative stress and inflammatory condition in human monocytic (THP-1) cells. Phytomedicine. 61: 152831.

Rjiba-TK, Ayed-Boussema I, Belarbia A, Achour A and Bacha H. 2012. Recombinant human erythropoietin prevents cisplatin-induced genotoxicity in rat liver and heart tissues via an antioxidant process. Drug and Chemical Toxicology. 35(2): 134-140.

Saha S and Ghosh S. 2012. Tinospora cordifolia: One plant, many roles. Ancient Science of Life. 31(4): 151.

Satoh M, Kashihara N, Fujimoto S, Horike H, Tokura T, Namikosh $\mathrm{T}$ and Makino H.2003. A novel free radical scavenger, edarabone, protects against cisplatin-induced acute renal damage in vitro and in vivo. Journal of Pharmacology and Experimental Therapeutics. 305(3): 1183-1190.

Sharma P, Dwivedee B P, Bisht D, Dash A K and Kumar D. 2019. The chemical constituents and diverse pharmacological importance of Tinospora cordifolia. Heliyon. 5(9): e02437.

Singh N, Singh S M and Shrivastava P. 2003. Immunomodulatory effect of Tinospora cordifolia in tumor-bearing host. Oriental Pharmacy and Experimental Medicine. 3(2): 72-79.

Spelman K, Burns J J, Nichols D, Winters N, Ottersberg S and Tenborg M. 2006. Modulation of cytokine expression by traditional medicines: a review of herbal immunomodulators. Alternative Medicine Review.11(2): 128.

Stanely M P Pand Menon V P. 2001. Antioxidant action of Tinospora cordifolia root extract in alloxan 
diabetic rats. Phytotherapy Research: An International Journal Devoted to Pharmacological and Toxicological Evaluation of Natural Product Derivatives. 15(3): 213-218.

Stephen T. 2005. Cisplatin and Chemical Engineering News 83:52.

Tomofuji, Takaaki, Daisuke Ekuni, Toshihiro Sanbe, Koichiro Irie, Tetsuji Azuma, Takayuki Maruyama, Naofumi Tamaki, Jun Murakami, Susumu Kokeguchi, and Tatsuo Yamamoto. 2009. Effects of vitamin C intake on gingival oxidative stress in rat periodontitis. Free Radical Biology and Medicine. 46: 163-168.

Topal I, Bilgin A O, Cimen F K, Kurt N, Suleyman Z, Bilgin Y and Altuner D. 2018. The effect of rutin on cisplatininduced oxidative cardiac damage in rats. Anatolian Journal of Cardiology. 20(3): 136.

Wang J H D, Zhang Q, Han Y, Jin S and Qi F. 2009. Resveratrol protects against Cisplatin-induced cardiotoxicity by alleviating oxidative damage. Cancer Biotherapy and Radiopharmaceuticals. 24(6): 675-680.
Yanez J A, Teng X W, Roupe K A, Fariss M $\mathrm{W}$ and Davies N M. 2003. Chemotherapy induced gastrointestinal toxicity in rats: involvement of mitochondrial DNA, gastrointestinal permeability and cyclooxygenase- 2 . Journal of Pharmacy and Pharmaceutical Sciences. 6(3): 308314.

Yoshizawa K, Tashiro M, Tezuka S, Uchiyama M, Uchida E and Yamada T. 2019. Eicosapentaenoic Acid Improves Cisplatin-Induced Muscle Atrophy Without Accompanying Body Weight Gain. Nutrition and cancer. 71(3): 439-443.

Zhao L, Xing C, Sun W, Hou G, Yang G and Yuan L. (2018). Lactobacillus supplementation prevents cisplatininduced cardiotoxicity possibly by inflammation inhibition. Cancer Chemotherapy and Pharmacology. 82(6): 999-1008.

Zhao L. 2019. Protective effects of trimetazidine and coenzyme Q10 on cisplatin-induced cardiotoxicity by alleviating oxidative stress and mitochondrial dysfunction. Anatolian Journal of Cardiology. 22(5): 232.

\section{How to cite this article:}

Nisaath Begum, P. Shiva Kumar, A. Gopala Reddy, B. Ramya, P. Kalyani, B. Anil Kumar and Usha Rani, M. 2021. A Study on Oxidative Stress Induced Cardiotoxicity by Cisplatin and Protective Evaluation by Tinospora cordifolia and vitamin C. Int.J.Curr.Microbiol.App.Sci. 10(04): 617-631. doi: https://doi.org/10.20546/ijcmas.2021.1004.062 